\title{
Effect of shade materials on microclimate of crossbred calves during summer
}

Reena Kamal ${ }^{1}$, Triveni Dutt ${ }^{1}$, B. H. M. Patel ${ }^{1}$, Amitava Dey², P. C. Chandran², S. K. Barari², Asit Chakrabarti² and Bharat Bhusan ${ }^{3}$

\begin{abstract}
1. Livestock Production and Management Section, Indian Veterinary Research Institute, Izatnagar, Bareilly, Uttar Pradesh, India; 2. Division of Livestock and Fisheries Management, ICAR-Research Complex for Eastern Region, Patna, Bihar, India; 3. Division of Animal Genetics and Breeding, Indian Veterinary Research Institute, Izatnagar, Bareilly, Uttar Pradesh, India.

Corresponding author: Reena Kamal, e-mail: dr.reenakamal@yahoo.com,

TD: jdeeivri@gmail.com, BHMP: mpatellpm@gmail.com, AD: amitavdey_icar@yahoo.co.in,

PCC: vetchandran@gmail.com, SKB: skbarari@yahoo.co.in, AC: asit1963@yahoo.com, BB: bhusan.drbharat@gmail.com Received: 09-07-2014, Revised: 04-08-2014, Accepted: 09-08-2014, Published online: 05-10-2014
\end{abstract}

doi: 10.14202/vetworld.2014.776-783. How to cite this article: Kamal R, Dutt T, Patel BH, Dey A, Chandran PC, Barari SK, Chakrabarti A, Bhusan B (2014) Effect of shade materials on microclimate of crossbred calves during summer, Veterinary World 7(10): 776-783.

\begin{abstract}
Aim: The present study was carried out on cattle and buffalo farm of Indian Veterinary Research Institute, Izatnagar (Uttar Pradesh) to determine the effect of different shade materials on physiological performance in Vrindavani crossbred calves during the summer.
\end{abstract}

Materials and Methods: Twenty-eight crossbred calves were divided into four groups viz. Thatch shading roof (T1), agro-net shading roof - $60 \%$ light diffusion (T2), asbestos with canvas shading roof (T3) and well-grown tree (T4). The recording of macro and micro climate as well as the physiological parameters viz. rectal temperature and respiration rate were recorded at 9:00 AM and 2:00 PM for 2 consecutive days at every fortnight interval.

Result: The microclimate viz. maximum and minimum, relative humidity, temperature humidity index and surface temperature of the roof was lower in T2 group in the summer season. The physiological responses viz. rectal temperature and respiration rate was significantly higher in $\mathrm{T} 4$.

Conclusion: During the summer season both thatch and agro-net shade material helped in better relieving the summer stress.

Keywords: crossbred calves, microclimate, rectal temperature, respiration rate, shade materials, summer.

\section{Introduction}

In general, calves are housed in groups in confined outdoor yards during the day that leave them exposed to episodes of high environmental temperatures, which can exceed their ability to dissipate body heat. Calves attempt to maintain a constant body temperature regardless of the outside temperature, and within a certain temperature range-called the thermoneutral zone-calves can accomplish this without expending extra energy. The boundaries of the thermoneutral zone are not constant and are not determined by the outside temperature alone. They are affected greatly by the effective ambient temperature experienced by the calf, which depends on air movement, moisture, hair coat, sunlight, bedding, and rumination. Many of these factors can be influenced by the housing and environment in which the calf is placed [1].

The ensuing heat stress has important implications for cattle welfare as well as a negative impact on health and production; in extreme cases resulting in death. It has been observed that radiation energy

Copyright: The authors. This article is an open access article licensed under the terms of the Creative Commons Attributin License (http:// creative commons.org/licenses/by/2.0) which permits unrestricted use, distribution and reproduction in any medium, provided the work is properly cited. flow on animal is $685 \mathrm{kcal} / \mathrm{m}^{2} \mathrm{~h}$, but actually only $340 \mathrm{kcal} / \mathrm{m}^{2} \mathrm{~h}$ from the direct solar radiation rest is by reflection by floor, dust, wall, etc. Therefore, to protect young calves from the extremes of sun and wind simple shading even in the open paddock above the manger is essential during early life. Placing a simple shade over an animal exposed to a hot environment and direct solar radiant energy from the sun cuts the radiant heat load on that animal by about $45 \%$ [2]. Solar radiation is a major factor in heat stress and increases heat gain by direct as well as indirect means [3]. Continued exposure to the direct sun results in loss of body water through evaporation resulting in dryness of the skin increased rectal temperature, respiration and pulse rates, off-feed and cessation of rumination leading to higher calf mortality, poor growth rate during summer.

Type of roof material generally decides the micro climate in the underneath covered area. The structure casting the shade should have at least one of the following properties: high reflectivity, low conductivity, low under-surface emissity, correct roof profile (slope), maximum practical height [4]. Although, many roofing materials available in the market and are in practice. Unfortunately, no roofing material has all the properties to assist dairy calves 
in maintaining normal body temperature. Based on thermal Conductivity $\left(\mathrm{Kcal} / \mathrm{M},{ }^{\circ} \mathrm{C}\right)$ thatch, plastic and asbestos are considered to be good. However thatch is not durable and asbestos is delicate and costly thus demands the type of roofing material that is durable and low thermal conductivity.

There are many ways to provide shade, but litthe is known about the importance of various design features of shade (e.g. blockage of solar radiation, shade amount/animal, etc.). Different roofing material, new materials have also been used to create shade for plants and animals. However, use of such material has become common in vegetable/flowers growing. Still, such materials are not popular among animal owners due to less awareness, reluctance and impact. Costs of improving the animal's environment must be realized by the benefits gained in improved animal productivity [5] used woven polypropylene fabric materials providing $80 \%$ shade for animal shades. Normal roof fitted with woven polypropylene shade cloth offered a more efficient way to minimize heat stress than a normal roof [6]. Plastic and fabric covered arch-frame structures (commonly referred to as alternative structures or greenhouses) represent the newest trend of housing systems used to raise calves. Soft covered (greenhouse and canvas) i.e., polyethylene material style barns for dairy cattle have caught the interest of the industry because of their apparently cheaper cost. Greenhouse barns provide a healthy environment for calves, heifers and cows [7].

Therefore, in the present study, to exploit positiveness of each roofing material, different combination was tried. To reduce the thermal conductivity of asbestos, canvas material were laid over the outer surface. To enrich the ventilation, agro net was used independently.

\section{Materials and Methods}

\section{Ethical approval}

The research program was conducted after the approval of the Institutional Animal Ethics Committee Indian Veterinary Research Institute (IVRI), Izatnagar, Bareilly.

\section{Location of the experiment}

The present study was conducted on Vrindavani cattle calves at the cattle and buffalo farm, IVRI, Izatnagar. The Institute is located at an altitude of $169 \mathrm{~m}$ above mean sea level, at the latitude of $28.22^{\circ} \mathrm{N}$ latitude and $79.24^{\circ} \mathrm{E}$ longitudes. The climate of the place touches both the extremes of hot (approximately $45^{\circ} \mathrm{C}$ ) and cold (approximately $5^{\circ} \mathrm{C}$ ), and relative humidity $(\mathrm{RH})$ ranges between $15 \%$ and $99 \%$. The average maximum and minimum values of air temperature during the last 3 years were $38.07^{\circ} \mathrm{C}$ and $7.43^{\circ} \mathrm{C}$ respectively, and the mean monthly $\mathrm{RH}$ ranged between $45.46 \%$ and $93.93 \%$. Average annual rainfall ranges from 90 to $120 \mathrm{~cm}$, most of which is received during July to September.

\section{Experimental calves}

Calves born during March and April (up to $1^{\text {st }}$ week) were utilized for the experiment. 28 calves were taken into the experiment after 3 days of their birth (after colostrum feeding) on a staggering basis. Thereafter, the calves were not allowed to suckle the dams and were artificially milk fed separately. Calves were allocated to one of the following treatments keeping average birth weight and sex into consideration. Each group was kept at different places, which had covered area as well as open area. However, different shade material was used for a covered area under each treatment in the following manner.

\section{Experimental design}

- Thatch shading roof (T1): Four inch thick layer of paddy straw fixed to bamboo the frame. Agro-net shading roof (T2): Material purchased from the market $(25 \mathrm{~m} \times 5.5 \mathrm{~m})$, which is green and black colored knitted fabric made out of $100 \%$ high-density polyethylene of international quality and is ultraviolet stabilized with 60\% light diffusion.

- Asbestos with canvas shading roof (T3): Commercially available asbestos was used, and canvas was laid over the outer surface ensuring 2-3 inch gap between them.

- Well grown tree (T4): Well-grown tree already available in the open paddock of the calf section was used. This tree was big enough to provide shade except mid-day. There was circular manger that facilitated the feeding, but there was no separate shade area.

\section{Design and floor space Requirement}

Outer boundary wall having manger of the calf's unit was used for the experiment. Long axis of the paddock was East-West orientation. Different shade material was used to make covered area measuring $1.5 \mathrm{~m} \times$ $1 \mathrm{~m}$ (excluding manger) for each treatment groups. The open paddock measuring $2 \mathrm{~m} \times 1 \mathrm{~m}$ was made using welded wire mesh. The calves were given an opportunity loiter freely in the above mentioned area. Height of shed at eves was $2 \mathrm{~m}$. Manger measured $40 \mathrm{~cm}$ width, $15 \mathrm{~cm}$ depth and $20 \mathrm{~cm}$ height at inner wall of manger. Calves had free access to fresh, clean and cold water shade area. All the treatment groups were kept on brick on edge floor.

\section{Feeding and management for the experimental animals}

The calves remained with dam for 2 days after calving. On the $3^{\text {rd }}$ day, calf was shifted to one of the treatment groups and maintained as per the standard feeding and management followed in the institute farm. The whole milk was fed to calves as per the above mentioned schedule. During the milk feeding period, milk was first boiled and then it cooled to lukewarm (body temperature) before feeding. While milk feeding calves were taken inside the calf shed and kept in individual pens. The desired quantity of 
milk was offered by pail method and left over was also recorded. Green fodder and calf starter were offered from $1^{\text {st }}$ week onwards. The common green fodder supplied was being Berseem/Maize/Jowar.

\section{Health and hygiene practices}

All the calves were reared under strict management and proper hygienic conditions throughout the period of the study. Deworming was done during $2^{\text {nd }}$ week of the calf's age. In the subsequent week, disbudding was also followed with precautions. Good sanitation of the pens, feeding utensils, water containers and surrounding experimental area was maintained during the period of the experiment. The pens were cleaned daily, and all hygienic precaution was taken to prevent the incidence of infectious and contagious diseases.

\section{Recording of parameters}

\section{Macro climate during experiment}

Daily environmental temperature (maximum and minimum) was measured by maximum and minimum thermometer. RH was estimated by psychrometeric chart by the help of dry and wet bulb reading. Temperature humidity index (THI) was calculated as per McDowell (1972) using the following formula:

$\mathrm{THI}=0.72$ (wet bulb temperature + dry bulb temperature) +40.6

Solar radiation was measured using Automatic Weather Station, Department of Physiology and Climatology, IVRI. Wind speed data were obtained from Automatic Weather Station, Department of Physiology and Climatology, IVRI.

\section{Microclimate in different experimental shed}

Daily temperature (maximum and minimum) was measured by maximum and minimum thermometer in sheds at 9:00 AM and 2:00 PM that was hanged by thread in a covered area underneath the roof. Daily RH at 9:00 AM and 2:00 PM was estimated by psychrometeric chart by the help of dry and wet bulb reading, which was hanged by thread in a covered area underneath the roof. THI was recorded as same as in macro climate on a daily basis. Surface temperature (ST) of roof both inside and outside ST of shade material was measured by infrared thermometer (ebro, TFI 220) at 9:00 AM and 2:00 PM at weekly interval.

\section{Physiological observation}

Rectal temperature and respiratory rates of calves were recorded at fortnightly intervals for 2 consecutive days at 9:00 AM and 2:00 PM. Rectal temperature was recorded by using a digital clinical thermometer. Respiration rate was counted from a distance by observing flank movements and expressed as counts per minute.

\section{Statistical analysis}

The data obtained from the study was analyzed as per the method described by [8].

\section{Results}

\section{Macro climate during summer}

The macroclimatic conditions were more stressful during last fortnights of the experimental period. The solar radiation ranged from $179.87 \pm 5.11$ to $211.20 \pm 4.89 \mathrm{~W} / \mathrm{m}^{2}$ during the course of the experiment, whereas wind speed varied from $0.31 \pm 0.06$ to $0.47 \pm 0.04 \mathrm{~m} / \mathrm{s}$. The mean ambient temperature ranged between $23.26 \pm 0.82^{\circ} \mathrm{C}$ to $33.65 \pm 0.22^{\circ} \mathrm{C}$. The $\mathrm{RH}$ during the experimental period at 9:00 AM ranged between $60.67 \pm 1.98 \%$ to $48.80 \pm 2.19 \%$, whereas at 2:00 PM it varied from $42.09 \pm 3.16 \%$ to $36.92 \pm 1.58 \%$. The mean RH during the observation period was ranged between $51.38 \pm 2.52 \%$ to $42.86 \pm 1.73 \%$. The THI at 9:00 AM varied between $69.64 \pm 0.80$ to $84.28 \pm 0.42$ and at 2:00 PM was ranged between $82.31 \pm 0.98$ to $89.90 \pm 0.35$ (Figure- 1 ).

\section{Minimum and maximum temperature $\left({ }^{\circ} \mathrm{C}\right)$ of microclimate}

The temperature at 9:00 AM during the first fortnight was $18.74 \pm 0.30,18.45 \pm 0.42,19.86 \pm 0.25$ and $18.28 \pm 0.53^{\circ} \mathrm{C}$, which increased to $26.47 \pm 0.42$, $20.33 \pm 0.55,24.67 \pm 0.30$ and $25.13 \pm 0.39^{\circ} \mathrm{C}$ under $\mathrm{T} 1$, T2, T3 and T4, respectively. Whereas corresponding value at 2:00 PM increases from 29.91 \pm 0.95 , $28.30 \pm 0.69,30.50 \pm 0.27$ and $30.27 \pm 0.66$ to $35.67 \pm 0.27$, $35.87 \pm 0.24,37.73 \pm 0.32$ and $36.93 \pm 0.45$ during last fortnight. The overall minimum temperature at 9:00 AM was $23.16 \pm 0.1,19.27 \pm 0.19,23.16 \pm 0.20$ and $23.09 \pm 0.25^{\circ} \mathrm{C}$, whereas at 2:00 PM $33.16 \pm 0.18$, $32.74 \pm 0.22$, $34.64 \pm 0.20$ and $34.61 \pm 0.30^{\circ} \mathrm{C}$ in $\mathrm{T} 1$, T2, $\mathrm{T} 3$ and $\mathrm{T} 4$ respectively. The overall minimum temperature at 9:00 AM was significantly lower $(p<0.05)$ in $\mathrm{T} 2$ as compared to other shade materials during all the fortnight, whereas maximum temperature was more $(\mathrm{p}<0.05)$ recorded in $\mathrm{T} 3\left(34.64 \pm 0.20^{\circ} \mathrm{C}\right)$, followed by T4 $\left(34.61 \pm 0.30^{\circ} \mathrm{C}\right)$ and least in $\mathrm{T} 2\left(32.74 \pm 0.22^{\circ} \mathrm{C}\right)$, followed by $\mathrm{T} 1\left(33.16 \pm 0.18^{\circ} \mathrm{C}\right)$.

\section{RH (\%) of micro climate}

The RH at 9:00 AM during the first fortnight was $59.51 \pm 1.55, \quad 51.33 \pm 2.12, \quad 81.46 \pm 2.21$ and $82.28 \pm 2.14 \%$, which increased to $60.33 \pm 2.53$, $39.87 \pm 0.53,65.67 \pm 2.05$ and $79.87 \pm 3.09 \%$ at last fortnight. Similarly, RH at 2:00 PM increased from $43.27 \pm 1.75,40.20 \pm 1.59,68.67 \pm 1.75$ and $69.93 \pm 1.73$ $\%$ to $48.01 \pm 1.98, \quad 44.36 \pm 0.32, \quad 55.77 \pm 1.59$ and

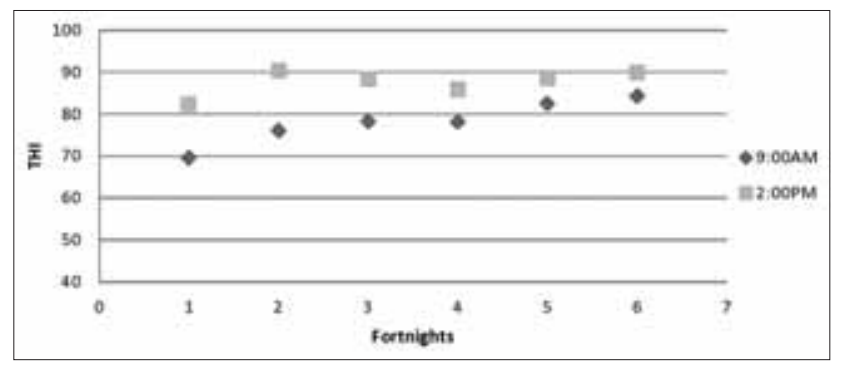

Figure-1: Temperature humidity index of macro climate during experiment. 
$67.63 \pm 2.73 \%$ for T1, T2, T3 and T4, respectively. The overall RH was $62.78 \pm 0.65,44.81 \pm 0.58,72.23 \pm 0.58$ and $76.42 \pm 0.58$ at $9: 00 \mathrm{AM}$ and $48.87 \pm 1.03$, $40.82 \pm 0.56,59.98 \pm 0.66$ and $66.27 \pm 0.59 \%$ at $2: 00$ $\mathrm{PM}$ in T1, T2, T3, and T4, respectively. The perusal table reveals that there was decreasing trend in the $\mathrm{RH}$ from third fortnight onwards in all the shade materials except in tree where there was no particular trend. Irrespective of treatment $\mathrm{RH}$ at 9:00 AM was significantly more $(\mathrm{p}<0.05)$ than at 2:00 PM. The RH at 9:00 AM and 2:00 PM was significantly more $(\mathrm{p}<0.05)$ in T4 $(76.42 \pm 0.58$ and $66.27 \pm 0.59 \%)$ followed by T3 $(72.23 \pm 0.58$ and $59.98 \pm 0.66 \%)$ and $\mathrm{T} 1(62.78 \pm 0.65$ and $48.87 \pm 1.03 \%)$ and was least in T2 (44.81 \pm 0.58 and $40.82 \pm 0.56 \%)$. Similar trend followed throughout the experiment.

\section{THI of micro climate}

The THI recorded fortnightly at 9:00 AM and 2:00 PM during the experimental period under different shade material are presented in (Figure-2). THI during the first fortnight was $64.89 \pm 0.92,64.46 \pm 0.89$, $67.34 \pm 0.81$ and $66.95 \pm 0.82$, which increased to $79.98 \pm 0.32,78.35 \pm 0.36,80.68 \pm 0.35$ and $81.54 \pm 0.41$ during the last fortnight under T1, T2, T3 and T4 respectively. Similarly, at 2:00 PM the THI increased from $74.39 \pm 0.87,74.68 \pm 0.77,80.39 \pm 0.81$ and $79.00 \pm 1.08$ to $84.28 \pm 0.30,84.38 \pm 0.48,86.15 \pm 0.36$ and $86.39 \pm 0.37$ for T1, T2, T3 and T4, respectively. The overall THI at 9:00 $\mathrm{AM}$ in $\mathrm{T} 1, \mathrm{~T} 2, \mathrm{~T} 3$, and $\mathrm{T} 4$ was $74.26 \pm 0.40$, $72.87 \pm 0.41,75.40 \pm 0.34$ and $76.12 \pm 0.41$, whereas at 2:00 PM was $80.72 \pm 0.29,79.68 \pm 0.35,82.86 \pm 0.33$ and $82.68 \pm 0.44$, respectively. The table reveals that the THI at 9:00 AM was significantly lower $(\mathrm{p}<0.05)$ from THI at 2:00 PM in all the treatments groups. The perusal table also showed that the minimum THI $(\mathrm{p}<0.05)$ was in $\mathrm{T} 2$ and maximum $(\mathrm{p}<0.05)$ was in $\mathrm{T} 4$, followed by T3 and T1 both at 9:00 AM and 2:00 PM throughout the fortnights except at third fortnight at 9:00 AM where there was no significant difference between the groups. The maximum THI was recorded during sixth fortnight at 9:00 AM was in T4 (81.54 \pm 0.41$)$, followed by T3 $(80.68 \pm 0.35)$, T1 $(79.98 \pm 0.32)$ and was minimum in T2 (78.35 \pm 0.36$)$. The corresponding value of THI at 2:00 PM was maximum in T4 (86.39 \pm 0.37$)$ and T3 (86.15 \pm 0.36$)$ and minimum in T1 (84.28 \pm 0.30$)$ and T2 (84.38 \pm 0.48$)$.

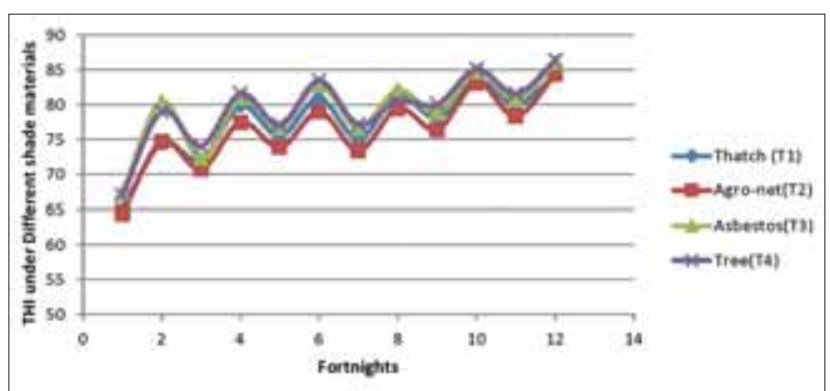

Figure-2: Temperature humidity index of micro climate under different shed.

\section{ST $\left({ }^{\circ} \mathrm{C}\right)$ of different shade material}

The ST both inside and outside of all the shade materials are given in Table-1. Throughout the experiment, the outside ST was significantly higher $(\mathrm{p}<0.05)$ than inside the surface in all the shade materials. The outside ST at 9.00 AM was significantly higher $(p<0.05)$ for asbestos, followed by thatch and lowest for agro-net. Similar pattern was also observed for outside ST at 2:00 PM except between asbestos and thatch, which did not differ significantly. Further, at 9.00 AM and 2:00 PM same trend was also observed for inside ST. Overall percentage of temperature reduction inside the surface compare to outside in $\mathrm{T} 1$, $\mathrm{T} 2$, and T3 was 43.58, 48.77 and $27.15 \%$, respectively.

\section{Physiological response}

The fortnight physiological responses of crossbred calves viz. rectal temperature and respiration rate during the morning (9:00 $\mathrm{AM}$ ) and afternoon (2:00 PM) are presented in Tables 2 and 3. The rectal temperature of calves at 2:00 PM was significantly higher $(p<0.05)$ then rectal temperature at 9:00 AM in all the groups throughout the experiment except T1 group that shows non-significant difference $(p<0.05)$ during second fortnights. The rectal temperature at 9:00 AM was higher in T3 grouped calves, whereas at 2:00 PM T3 showed the higher $(\mathrm{p}<0.05)$ rectal temperature followed by $\mathrm{T} 4$.

The respiration rate of calves at 2:00 PM was significantly higher $(\mathrm{p}<0.05)$ than respiration rate at 9:00 AM in all the groups throughout the experiment. At 9:00 AM respiration rate were significantly higher $(\mathrm{p}<0.05)$ in T3 whereas at 2:00 PM respiration rate was significantly higher $(\mathrm{p}<0.05)$ in T4 and T3 than $\mathrm{T} 2$ and $\mathrm{T} 1$.

\section{Discussion}

Under different shade material, maximum temperature could be observed in T3 followed by T4. The shade material used in T3 might be unable to cut down the heat load falling on it through radiation, obviously it is heated up, and heat is passed to micro-environment in shed, which is in agreement with [9]. Whereas, T4 might have lesser protection from direct solar radiation. T2 was able to keep the mean maximum temperature slightly below macro-environment indicating the superior protective capacity of shade material used in T2 in comparison to other shade materials. The present finding are in agreement with [10] who reported that the maximum temperature, as well as minimum temperature in thatch and mud plaster roof, was lower $(p<0.05)$ than loose house covered with asbestos sheet. Similarly [11], observed that house roofed with asbestos had higher maximum temperature and lower minimum temperature than the tile-roofed house [12]. found lower maximum temperature in shed having tile roof as compared to GI sheet, polythene sheet.

Higher RH in T4 might be due to the presence of animals, urine, and water as well as respiration of tree. The RH under T2 was lower. This might be 
Table-1: Mean \pm SEM of ST $\left({ }^{\circ} \mathrm{C}\right)$ of different shade material*.

\begin{tabular}{|c|c|c|c|c|c|}
\hline Fortnights & Surface & Time (T1) & Thatch (T2) & Agro-net (T3) & Asbestos (T4) \\
\hline \multirow[t]{6}{*}{$\mathrm{I}$} & Roof outside & 9:00 AM & $53.89 \pm 0.56^{b}$ & $39.17 \pm 0.00^{a}$ & $54.73 \pm 0.84^{b}$ \\
\hline & & 2:00 PM & $49.73 \pm 0.84^{b}$ & $36.81 \pm 3.75^{a}$ & $54.72 \pm 2.50^{b}$ \\
\hline & & Overall & $51.81 \pm 0.70^{\mathrm{b}}$ & $37.99 \pm 1.88^{a}$ & $54.73 \pm 0.84^{b}$ \\
\hline & Roof inside & 9:00 AM & $34.17 \pm 0.28^{b}$ & $29.17 \pm 0.56^{a}$ & $49.72 \pm 1.39^{c}$ \\
\hline & & 2:00 PM & $31.12 \pm 0.56^{b}$ & $23.19 \pm 1.25^{\mathrm{a}}$ & $50.00 \pm 0.00^{c}$ \\
\hline & & Overall & $32.64 \pm 0.42^{\mathrm{b}}$ & $26.18 \pm 0.90^{\mathrm{a}}$ & $49.87 \pm 0.70^{c}$ \\
\hline \multirow[t]{6}{*}{11} & Roof outside & 9:00 AM & $43.75 \pm 2.36$ & $37.50 \pm 2.78$ & $56.11 \pm 7.50$ \\
\hline & & 2:00 PM & $51.95 \pm 1.39^{\mathrm{ab}}$ & $35.56 \pm 1.12^{\mathrm{a}}$ & $67.09 \pm 9.31^{\mathrm{b}}$ \\
\hline & & Overall & $47.85 \pm 1.88^{b}$ & $36.53 \pm 0.84^{a}$ & $61.60 \pm 0.91^{c}$ \\
\hline & Roof inside & 9:00 AM & $31.53 \pm 0.42^{\mathrm{ab}}$ & $18.61 \pm 3.61^{a}$ & $40.28 \pm 4.17^{b}$ \\
\hline & & 2:00 PM & $37.22 \pm 2.22^{b}$ & $21.39 \pm 1.95^{\mathrm{a}}$ & $45.70 \pm 2.37^{b}$ \\
\hline & & Overall & $34.38 \pm 0.91^{\mathrm{b}}$ & $20.00 \pm 0.83^{a}$ & $42.99 \pm 0.91^{c}$ \\
\hline \multirow[t]{6}{*}{111} & Roof outside & 9:00 AM & $35.56 \pm 10.56$ & $28.61 \pm 6.11$ & $36.53 \pm 12.09$ \\
\hline & & 2:00 PM & $39.72 \pm 13.61$ & $30.00 \pm 6.67$ & $50.98 \pm 25.42$ \\
\hline & & Overall & $37.64 \pm 12.08$ & $29.31 \pm 6.39$ & $43.75 \pm 18.75$ \\
\hline & Roof inside & 9:00 AM & $26.81 \pm 4.31$ & $15.14 \pm 0.14$ & $30.14 \pm 5.97$ \\
\hline & & 2:00 PM & $31.39 \pm 8.06$ & $19.45 \pm 3.89$ & $36.53 \pm 11.53$ \\
\hline & & Overall & $29.10 \pm 6.18$ & $17.30 \pm 1.88$ & $33.33 \pm 8.75$ \\
\hline \multirow[t]{6}{*}{ IV } & Roof outside & 9:00 AM & $47.92 \pm 5.14$ & $35.70 \pm 0.70$ & $47.78 \pm 0.00$ \\
\hline & & 2:00 PM & $55.14 \pm 2.36^{b}$ & $40.83 \pm 1.39^{a}$ & $56.39 \pm 3.33^{b}$ \\
\hline & & Overall & $51.53 \pm 3.75^{b}$ & $38.27 \pm 1.05^{a}$ & $52.09 \pm 1.67^{\mathrm{b}}$ \\
\hline & Roof inside & 9:00 AM & $33.89 \pm 0.83^{b}$ & $18.20 \pm 2.64^{a}$ & $38.06 \pm 0.00^{b}$ \\
\hline & & 2:00 PM & $35.70 \pm 0.70^{\mathrm{ab}}$ & $22.78 \pm 7.22^{\mathrm{a}}$ & $47.37 \pm 3.20^{\mathrm{b}}$ \\
\hline & & Overall & $34.79 \pm 0.07^{b}$ & $20.49 \pm 4.93^{a}$ & $42.71 \pm 1.60^{b}$ \\
\hline \multirow[t]{6}{*}{ v } & Roof outside & 9:00 AM & $42.92 \pm 3.20^{\mathrm{ab}}$ & $35.97 \pm 0.97^{a}$ & $50.56 \pm 1.67^{b}$ \\
\hline & & 2:00 PM & $54.86 \pm 5.97$ & $43.61 \pm 0.83$ & $62.92 \pm 7.92$ \\
\hline & & Overall & $48.89 \pm 4.58$ & $39.79 \pm 0.90$ & $56.74 \pm 4.80$ \\
\hline & Roof inside & 9:00 AM & $33.75 \pm 1.25^{\mathrm{ab}}$ & $23.75 \pm 3.75^{\mathrm{a}}$ & $36.67 \pm 1.11^{\mathrm{b}}$ \\
\hline & & 2:00 PM & $40.98 \pm 2.09$ & $33.47 \pm 6.25$ & $52.50 \pm 6.94$ \\
\hline & & Overall & $37.36 \pm 1.67$ & $28.61 \pm 5.00$ & $44.59 \pm 4.03$ \\
\hline \multirow[t]{6}{*}{ VI } & Roof outside & 9:00 AM & $49.45 \pm 0.56^{b}$ & $35.97 \pm 0.14^{a}$ & $67.92 \pm 0.42^{c}$ \\
\hline & & 2:00 PM & $66.11 \pm 0.00^{b}$ & $50.56 \pm 0.00^{a}$ & $82.78 \pm 0.56^{c}$ \\
\hline & & Overall & $57.78 \pm 0.28^{b}$ & $43.26 \pm 0.07^{a}$ & $75.35 \pm 0.49^{c}$ \\
\hline & Roof inside & 9:00 AM & $36.25 \pm 0.42^{b}$ & $32.78 \pm 0.56^{a}$ & $44.45 \pm 0.56^{c}$ \\
\hline & & 2:00 PM & $38.75 \pm 0.14^{a}$ & $44.72 \pm 0.00^{\mathrm{b}}$ & $70.00 \pm 1.11^{\mathrm{c}}$ \\
\hline & & Overall & $37.50 \pm 0.28^{a}$ & $38.75 \pm 0.28^{a}$ & $57.23 \pm 0.84^{\mathrm{b}}$ \\
\hline \multirow[t]{6}{*}{ Overall } & Roof outside & 9:00 AM & $45.58 \pm 2.02^{b}$ & $35.49 \pm 0.86^{a}$ & $52.27 \pm 1.25^{c}$ \\
\hline & & 2:00 PM & $52.92 \pm 3.24^{\mathrm{ab}}$ & $39.56 \pm 1.04^{a}$ & $62.48 \pm 6.23^{b}$ \\
\hline & & Overall & $49.25 \pm 2.63^{\mathrm{ab}}$ & $37.52 \pm 0.95^{a}$ & $57.37 \pm 3.74^{b}$ \\
\hline & Roof inside & 9:00 AM & $32.73 \pm 0.83^{b}$ & $22.94 \pm 0.44^{a}$ & $39.88 \pm 0.81^{c}$ \\
\hline & & 2:00 PM & $35.86 \pm 2.30^{\mathrm{ab}}$ & $27.50 \pm 3.01^{a}$ & $50.35 \pm 4.19^{b}$ \\
\hline & & Overall (\%) & $34.30 \pm 1.57^{b}(43.58)$ & $25.22 \pm 1.72^{\mathrm{a}}(48.77)$ & $45.12 \pm 2.50^{c}(27.15)$ \\
\hline
\end{tabular}

Means bearing different Superscript differ significantly $(p<0.05)$ row wise. Value given in parenthesis indicate overall percentage of temperature reduction inside the surface compare to outside. *Tree: No reading taken as no roofing material used. ST=Surface temperature, SEM=Standard error of the mean

due to the fact that agro-net allows the floor below to dry out quickly and provided proper ventilation during summer [12] observed higher RH (maximum and minimum) in plastic shade roof when compared to thatch, GI sheets and tile roof and was corroborates earlier reports also [13,14].

Morning and evening THI values exceeded critical value of 72, except in T2 during morning hr. This indicated that the animals were in stress micro-environment in all the shade materials. In general, mild stress is initiated at a THI $>74$, while at THI $>80$ stress becomes severe, including panting, standing up to facilitate evaporation from the skin $[15,12]$. However, minimum THI in group T2 as compared to other shade materials might be due to less penetration of solar radiation inside the shed [16,17] reported significantly higher $(\mathrm{p}<0.05)$ THI at evening than morning hour and concluded that higher THI in loose house covered with asbestos sheet provided thermal stress as low maximum temperature and low THI in thatch and mud roof house created better microenvironment [18] found no significant difference between mud plaster and thatch roof. The percentage of temperature reduction in T2 shade material clearly indicated that the agro-net was better to reduce the solar radiation compared to other shade materials.

The effect of microclimate created by different shade materials can be clearly evaluated by the physiological performance of the calves. The significant rise in rectal temperature in $\mathrm{T} 3$ followed by $\mathrm{T} 4$ grouped calves might be due to heated asbestos and direct solar radiation effect on experimental calves during experimental period. Inability to eliminate excess heat might probably have led to the rise in rectal temperature. 
Table-2: Mean \pm SEM of rectal temperature $\left({ }^{\circ} \mathrm{C}\right)$.

\begin{tabular}{|c|c|c|c|c|c|}
\hline Fortnights & Time & Thatch (T1) & Agro-net (T2) & Asbestos (T3) & Tree (T4) \\
\hline \multirow[t]{3}{*}{1} & 9:00 AM & $38.93 \pm 0.15$ & $38.99 \pm 0.06$ & $39.05 \pm 0.07$ & $38.97 \pm 0.05$ \\
\hline & 2:00 PM & $39.10 \pm 0.09$ & $39.06 \pm 0.07$ & $39.20 \pm 0.09$ & $39.18 \pm 0.09$ \\
\hline & Overall & $39.01 \pm 0.11$ & $39.02 \pm 0.06$ & $39.12 \pm 0.08$ & $39.07 \pm 0.08$ \\
\hline \multirow[t]{3}{*}{ II } & 9:00 AM & $39.14 \pm 0.08^{\mathrm{ab} *}$ & $38.97 \pm 0.07^{a}$ & $39.20 \pm 0.05^{b}$ & $39.13 \pm 0.04^{\mathrm{ab}}$ \\
\hline & $2: 00 \mathrm{PM}$ & $39.02 \pm 0.09^{a *}$ & $39.09 \pm 0.07^{a b}$ & $39.25 \pm 0.04^{\mathrm{bc}}$ & $39.37 \pm 0.09 c$ \\
\hline & Overall & $39.08 \pm 0.07^{a b}$ & $39.03 \pm 0.07^{a}$ & $39.23 \pm 0.04^{\mathrm{ab}}$ & $39.25 \pm 0.09^{b}$ \\
\hline \multirow[t]{3}{*}{ III } & 9:00 AM & $39.06 \pm 0.11^{\mathrm{a}}$ & $39.06 \pm 0.04^{a}$ & $39.48 \pm 0.03^{b}$ & $39.18 \pm 0.04^{a}$ \\
\hline & $2: 00 \mathrm{PM}$ & $39.16 \pm 0.11^{a}$ & $39.16 \pm 0.04^{a}$ & $39.61 \pm 0.03^{b}$ & $39.29 \pm 0.05^{a}$ \\
\hline & Overall & $39.11 \pm 0.11^{\mathrm{a}}$ & $39.11 \pm 0.04^{a}$ & $39.55 \pm 0.03^{b}$ & $39.24 \pm 0.05^{a}$ \\
\hline \multirow[t]{3}{*}{ IV } & 9:00 AM & $38.97 \pm 0.06^{a}$ & $39.11 \pm 0.07^{a}$ & $39.52 \pm 0.03^{b}$ & $39.06 \pm 0.04^{a}$ \\
\hline & 2:00 PM & $39.04 \pm 0.05^{\mathrm{a}}$ & $39.18 \pm 0.06^{b}$ & $39.65 \pm 0.03^{c}$ & $39.23 \pm 0.05^{b}$ \\
\hline & Overall & $39.00 \pm 0.05^{a}$ & $39.15 \pm 0.06^{a}$ & $39.58 \pm 0.03^{b}$ & $39.15 \pm 0.06^{a}$ \\
\hline \multirow[t]{3}{*}{ V } & 9:00 AM & $39.29 \pm 0.08^{a b}$ & $39.50 \pm 0.06^{b}$ & $39.49 \pm 0.05^{b}$ & $39.20 \pm 0.04^{a}$ \\
\hline & 2:00 PM & $39.37 \pm 0.09$ & $39.56 \pm 0.06$ & $39.52 \pm 0.07$ & $39.33 \pm 0.11$ \\
\hline & Overall & $39.33 \pm 0.08^{a b}$ & $39.53 \pm 0.06^{b}$ & $39.50 \pm 0.05^{\mathrm{ab}}$ & $39.26 \pm 0.11^{a}$ \\
\hline \multirow[t]{3}{*}{ VI } & 9:00 AM & $39.27 \pm 0.05^{a b}$ & $39.11 \pm 0.07^{a}$ & $39.45 \pm 0.08^{b}$ & $39.45 \pm 0.04^{b}$ \\
\hline & 2:00 PM & $39.44 \pm 0.04^{b}$ & $39.18 \pm 0.06^{a}$ & $39.70 \pm 0.12^{c}$ & $39.65 \pm 0.09^{b c}$ \\
\hline & Overall & $39.35 \pm 0.04^{b}$ & $39.15 \pm 0.06^{a}$ & $39.57 \pm 0.09^{c}$ & $39.55 \pm 0.07$ \\
\hline \multirow[t]{3}{*}{ Overall } & 9:00 AM & $39.11 \pm 0.06^{a}$ & $39.12 \pm 0.01^{\mathrm{a}}$ & $39.37 \pm 0.03^{b}$ & $39.17 \pm 0.02^{a}$ \\
\hline & 2:00 PM & $39.19 \pm 0.05^{\mathrm{a}}$ & $39.20 \pm 0.02^{a}$ & $39.49 \pm 0.02^{c}$ & $39.34 \pm 0.04^{b}$ \\
\hline & Overall & $39.15 \pm 0.05^{a}$ & $39.18 \pm 0.02^{\mathrm{a}}$ & $39.44 \pm 0.02^{c}$ & $39.28 \pm 0.04^{b}$ \\
\hline
\end{tabular}

Means bearing different superscript differ significantly $(p<0.05)$ row wise. *Non-significant between 9:00 AM and 2:00 $\mathrm{PM}$ within the treatments. SEM=Standard error of the mean

Table-3: Mean \pm SEM of respiration rate (per minutes).

\begin{tabular}{|c|c|c|c|c|c|}
\hline Fortnights & Time & Thatch (T1) & Agro-net (T2) & Asbestos (T3) & Tree (T4) \\
\hline \multirow[t]{3}{*}{1} & 9:00 AM & $21.71 \pm 0.67^{\mathrm{ab}}$ & $22.21 \pm 0.37^{b}$ & $24.64 \pm 0.53^{c}$ & $20.21 \pm 0.52^{\mathrm{a}}$ \\
\hline & $2: 00 \mathrm{PM}$ & $31.50 \pm 0.48^{a}$ & $32.79 \pm 0.57^{a}$ & $50.00 \pm 0.66^{b}$ & $55.29 \pm 1.10^{c}$ \\
\hline & Overall & $26.71 \pm 0.34^{a}$ & $27.32 \pm 0.28^{a}$ & $38.00 \pm 0.37^{b}$ & $38.25 \pm 0.63^{b}$ \\
\hline \multirow[t]{3}{*}{ II } & 9:00 AM & $21.93 \pm 0.55^{\mathrm{a}}$ & $21.86 \pm 0.35^{\mathrm{a}}$ & $27.00 \pm 0.50^{b}$ & $21.57 \pm 0.44^{a}$ \\
\hline & 2:00 PM & $31.50 \pm 0.44^{a}$ & $31.86 \pm 0.65^{a}$ & $50.00 \pm 0.66^{b}$ & $54.21 \pm 0.73^{c}$ \\
\hline & Overall & $26.89 \pm 0.24^{a}$ & $27.39 \pm 0.33^{a}$ & $39.07 \pm 0.32^{c}$ & $38.04 \pm 0.35^{b}$ \\
\hline \multirow[t]{3}{*}{ III } & 9:00 AM & $21.79 \pm 0.32^{\mathrm{a}}$ & $22.64 \pm 0.36^{a}$ & $28.14 \pm 0.40^{\mathrm{b}}$ & $21.71 \pm 0.40^{a}$ \\
\hline & 2:00 PM & $32.00 \pm 0.44^{a}$ & $32.14 \pm 0.72^{\mathrm{a}}$ & $50.00 \pm 0.66^{b}$ & $54.36 \pm 0.71^{c}$ \\
\hline & Overall & $26.89 \pm 0.24^{\mathrm{a}}$ & $27.39 \pm 0.33^{a}$ & $39.07 \pm 0.32^{c}$ & $38.04 \pm 0.35^{b}$ \\
\hline \multirow[t]{3}{*}{ IV } & 9:00 AM & $22.29 \pm 0.29^{\mathrm{a}}$ & $22.64 \pm 0.36^{\mathrm{a}}$ & $28.43 \pm 0.39^{b}$ & $21.57 \pm 0.43^{\mathrm{a}}$ \\
\hline & 2:00 PM & $32.50 \pm 0.49^{a}$ & $32.29 \pm 0.66^{a}$ & $50.00 \pm 0.66^{b}$ & $54.14 \pm 0.77^{c}$ \\
\hline & Overall & $27.39 \pm 0.24^{a}$ & $27.46 \pm 0.32^{\mathrm{a}}$ & $39.21 \pm 0.35^{c}$ & $37.86 \pm 0.40^{b}$ \\
\hline \multirow[t]{3}{*}{ V } & 9:00 AM & $22.86 \pm 0.31^{\mathrm{a}}$ & $22.50 \pm 0.33^{a}$ & $28.93 \pm 0.41^{b}$ & $22.07 \pm 0.44^{a}$ \\
\hline & 2:00 PM & $31.86 \pm 0.55^{\mathrm{a}}$ & $31.50 \pm 0.61^{a}$ & $48.93 \pm 0.51^{b}$ & $54.50 \pm 0.82^{c}$ \\
\hline & Overall & $27.36 \pm 0.32^{\mathrm{a}}$ & $27.00 \pm 0.30^{a}$ & $38.93 \pm 0.35^{c}$ & $38.29 \pm 0.48^{b}$ \\
\hline \multirow[t]{3}{*}{ VI } & 9:00 AM & $23.79 \pm 0.28^{\mathrm{b}}$ & $22.43 \pm 0.29^{a}$ & $29.71 \pm 0.40^{c}$ & $23.07 \pm 0.44^{\mathrm{ab}}$ \\
\hline & 2:00 PM & $32.57 \pm 0.63^{a}$ & $30.86 \pm 0.58^{a}$ & $49.43 \pm 0.49^{b}$ & $55.14 \pm 0.73^{c}$ \\
\hline & Overall & $28.18 \pm 0.38^{\mathrm{b}}$ & $26.64 \pm 0.31^{a}$ & $39.57 \pm 0.34^{c}$ & $39.11 \pm 0.40^{c}$ \\
\hline \multirow[t]{3}{*}{ Overall } & 9:00 AM & $22.39 \pm 0.30^{\mathrm{a}}$ & $22.38 \pm 0.30^{a}$ & $27.81 \pm 0.33^{b}$ & $21.70 \pm 0.39^{a}$ \\
\hline & 2:00 PM & $31.99 \pm 0.38^{a}$ & $31.90 \pm 0.59^{a}$ & $49.72 \pm 0.51^{b}$ & $54.61 \pm 0.63^{c}$ \\
\hline & Overall & $27.24 \pm 0.19^{a}$ & $27.20 \pm 0.28^{a}$ & $38.98 \pm 0.28^{b}$ & $38.26 \pm 0.34^{b}$ \\
\hline
\end{tabular}

Mean bearing different Superscript differ significantly $(p<0.05)$ row wise. Means values between 9:00 AM and 2:00 PM differ significantly $(p<0.05)$ within the treatment. SEM=Standard error of the mean

The present finding are in agreement with [19] who concluded that cows provided with more protection (99\% shade) from solar radiation as compared to $50 \%$ shade and no shade) had lower rectal temperature with higher level of ambient solar radiation [20] reported significantly higher $(\mathrm{p}<0.05)$ differences among the mean values of rectal temperature during summer under thatch roof $(39.49 \pm 0.05)$ and under tin shed (39.54 \pm 0.05$)$, which clearly indicated the inability of the kids housed in tin shed to make up with the higher environmental temperature [21] also reported significant difference among thatch roof shed, literoof and asbestos roof shed during hot summer [6], found significantly lower mean rectal temperature $\left(38.56^{\circ} \mathrm{C}\right)$ in shade cloth than that of the cows housed under normal roofing $\left(39.86^{\circ} \mathrm{C}\right)$. On the other hand [22] reported that in crossbred calves body temperature was not affected $(\mathrm{p}<0.05)$ by modification in the housing system.

The change in respiration rate was observed to be related with discomfort and was noticed that the increase was mainly due to exposure to greater intensity of solar radiation [23]. At higher temperature, the respiration rate was increased rapidly to about 
8-10 times the normal values in calves. The higher respiration rate in T4 and T3 might be attributed to more heat load which was get rid of by increased pulmonary evaporative cooling through respiratory channel [24]. The present finding is also in agreement with the observation of [25] who reported higher RR during afternoon than morning hr. in crossbred calves during summer [22] observed higher $(\mathrm{p}<0.05)$ respiration counts in loose house as compared to those animals kept in thatch house [6], found significantly lower respiration rate (61.97 breaths/min) in shade cloth than that of the cows housed under normal roofing (85.16 breaths/min) [26] reported increased respiration rate with increase in surrounding heat and observed that this increase was more marked in the $2.4 \mathrm{~m}^{2}$ shade/ cow and no shade treatments than in the $9.6 \mathrm{~m}^{2}$ shade/ cow treatments. These results indicated that cattle use shade to prevent an increase in internal body temperature, but this heat mitigation strategy is only effective if a sufficient amount of shade is provided.

\section{Conclusion}

During the summer season provision of agronet followed by thatch as shade materials in an open paddock provided favorable micro-environment to the crossbred calves resulted in keeping physiological responses in normal range. Asbestos sheet could not provide proper micro climate to calves that were witnessed high physiological values. Calves kept under tree also had high physiological values which indicate that tree was also insufficient to provide better micro-environment to calves during the summer. It can be concluded that agro-net could be suggested as shade material for summer for cattle, however durability of the material is to be worked out.

\section{Authors' Contributions}

RK performed the experiment under the guidance of TD and BHMP who also designed the experiment. Manuscript preparation was supervised, reviewed and edited by $\mathrm{AD}, \mathrm{PPC}, \mathrm{SKB}, \mathrm{AC}$ and $\mathrm{BB}$. All authors read and approved the final manuscript.

\section{Acknowledgments}

The authors are grateful to Director Indian Veterinary Research Institute, Izatnagar, Bareilly, Uttar Pradesh for undertaking this work and for providing necessary facilities and funds to carry out the present research work.

\section{Competing I nterests}

The authors declare that they have no competing interests.

\section{References}

1. Jones, C. and Heinrichs, J. (2013) Heat Stress in Dairy Calves. Available from: http://www.extension.psu.edu/ animals/dairy/nutrition/calves/feeding/heat-stress-indairy-calves/extension_publication_file. Last accessed on 25.07.2013.
2. Blackshaw, J.K. and Blackshaw, A.W. (1994) Heat stress in cattle and the effect of shade on production and behavior: A review. Aust. J. Exp. Agric., 34: 285-295.

3. Berman, A. and Horovitz T. (2012) Radiant heat loss, an unexploited path for heat stress reduction in shaded cattle. J. Dairy Sci., 95(6): 3021-31.

4. Haque, N. and Hussain, S.A. (2011) Dairy Articles Available from: http://www.Housing Design To Reduce Stress doc mht. Last accessed on 16.06.2013.

5. Atkenson, G.W. and Bickert, B. (1997) Open holding pens: A need for summertime shade. Mich. Dairy Rev.2 (3):14.

6. Khongdee, S., Sripoon, S., Chousawai, S., Hinch, G., Chaiyabutr, N., Markvichitr, K. and Vajrabukka, C. (2010) The effect of modified roofing on the milk yield and reproductive performance of heat-stressed dairy cows under hot-humid conditions. Anim. Sci. J.,81(5): 606-11.

7. Available from: http:/www.Oehmsen.com/-Green house barns for dairy housing. Last accessed on 16.06.2013.

8. Snedecor, F.W. and Cochran, W.G. (1994) Stastical Methods. $8^{\text {th }}$ ed. Oxford and IBH Publishing Co, Calcutta.

9. Macfarlane, W.C (1981) The housing of large mammals in hot climates. In: Clarks, J.A. editor. Environmental Aspects of Housing for Animals Production. Butterworth, London. p 259-283.

10. Jat, R.P. and Yadav, B.L. (2010) Growth and behavioural pattern of buffalo calves under different shelter modifications during winter. Indian J. Anim. Sci., 80(7): 686-689.

11. Sivakumar, K., Muralidharan, M.R., Viswanathan, K. Radhakrishnan, K. (2002) Microclimate and production performance of commercial layers under different roof types and rearing systems. Indian J. Poul. Sci., 37(3): 258-263.

12. Roy, P.K. and Chatterjee, A. (2010) Effect of different types of dairy cattle shelters on micro-climatic variables in rural West Bengal. Indian J. Anim. Sci., 80(8): 781-784.

13. Sharma, P. and Singh, K. (2002) Effect of shelter systems on environmental variables. Indian J. Anim. Sci., 72(9): 806-809.

14. Kaur and Singh, J. (2004) Effect of building design on thermal comfort inside different dairy shelter. Livest. Int., 84(4): 25-10.

15. Singh, S.V. and Upadhyay, R.C. (2009) Thermal stress on physiological functions, thermal balance and milk production in Karan Fries and Sahiwal cows. Indian Vet. J., 86(2): 141-144.

16. Singh, Y. (2000) Effect of certain managemental practices on the performance of buffalo heifers. "Ph. D Thesis" Submitted to CCS Haryana Agricultural University, Hisar, India.

17. Jat, R.P., Gupta, L.R. and Yadav, B.L. (2005) Effect of roof modification in loose house on intake and utilization of nutrients in buffalo calves during rainy season. Indian $J$. Anim. Sci., 58(1): 54-57.

18. Shekhawat, L.S. and Chaudhary, J.L. (2012) Effect of roof modifications in loose house on intake and utilization of nutrients and milk yield in lactating crossbred cows during winter season. J. Dairy Sci., 65(6): 501-07.

19. Tucker, C.B., Rogers, A.R. and Schütz, K.E. (2008) Effect of solar radiation on dairy cattle behaviour, use of shade and body temperature in a pasture-based system. Appl. Anim. Behav. Sci., 109: 141-154.

20. Patil, R.A., Karanjkar, L.M., Jadhav, V.S., and Narwade, S.G. (2008) (Marathwada Agricultural University, Parbhani (India) Department of animal husbandry and dairy science) Response in growth of Osmanabadi weaned kids to various housing patterns. Indian J. Anim. Res., 42(1): 29-33.

21. Kumar, P., Singh, K. and Sood, S.B. (1990) Effect of micro-environment within different types of sheds on physiological responses in Jamunapari goats in hot semi-arid zone. Indian J. Anim. Res., 24: 93-100.

22. Yazdani, A.R. and Gupta, L.R. (2000) Effect of housing and feeding system on feed utilization and physiological responses in crossbred Calves. Indian J. Dairy Sci., 53: 88-92. 
23. Das, S.K., Upadhyay, R.C. and Madan, M.L. (1999) Heat stress in Murrah buffalo calves. Livest. Prod. Sci., 61: 71-78.

24. Ganaie, A.H., Shanker, G., Nazir A., Bumla, N.A., Ghasura R.S., Mir, N.A., Wani, S.A. and Dudhatra, G.B. (2013) Biochemical and physiological changes during thermal stress in Bovines. J. Vet. Sci. Technol., 4: 1.

25. Soley, M.J. and Singh, S.V. (2001) 'Physiological and haematological responses of crossbred males under different housing conditions'. M.Sc. Thesis, Dairy Science College, NDRI, Karnal-132001.

26. Schütz, K.E., Rogers, A.R., Poulouin, Y.A., Cox, N.R. and Tucker, C.B. (2010) The amount of shade influences the behaviour and physiology of dairy cattle. J. Dairy Sci., 93: $125-233$

$* * * * * * * *$ 